\title{
Integrated Health Unit of a Community Health Department Creating Awareness on Nutrition, Hypertension, Diabetes and Mental Health in a Slum and Resettlement Colony in Delhi
}

\author{
Joyce Felicia Vaghela', Molly Roy ${ }^{2}$, Kriti Vaish $^{3}$, Ravi Mishra ${ }^{4}$, Abha Mangal 5 \\ $1,2,3,4,5$ Community Health Department, St. Stephen's Hospital, Tis Hazari, Delhi, India. \\ DOI: https://doi.org/10.24321/2455.9199.201909
}

\section{I $\quad \mathbf{N} \quad \mathbf{F} \quad \mathbf{O}$}

\section{Corresponding Author:}

Joyce Felicia Vaghela, Community Health Department, St. Stephen's Hospital, Tis Hazari, Delhi, India.

E-mail Id:

joycevaghela@gmail.com

Orcid Id:

https://orcid.org/0000-0001-7839-7501

How to cite this article:

Vaghela JF, Roy M, Vaish K, Mishra R, Mangal A. Integrated Health Unit of a Community Health Department Creating Awareness on Nutrition, Hypertension, Diabetes and Mental Health in a Slum and Resettlement Colony in Delhi. Int $J$ HealthCare Edu \& Med Inform 2019; 6(2): 23-32.

Date of Submission: 2020-06-23

Date of Acceptance: $2020-07-27$

\section{$\begin{array}{llllllll}\mathbf{A} & \mathbf{B} & \mathbf{S} & \mathbf{T} & \mathbf{R} & \mathbf{A} & \mathbf{C} & \mathbf{T}\end{array}$}

Background: A slum and Resettlement Colony in a Metro is always vulnerable to diseases, social evils, political instigations and riots etc. The Community Health Department of a Tertiary Care Hospital which is situated in one such area has an Integrated Health Unit with 6 Auxiliary Nurse Midwives (ANMs). The aim of this study is to find out whether there is an increase in the knowledge of area population regarding Nutrition, Hypertension, Diabetes, and Mental Health when Health education was imparted using Health Modules.

Methodology: A little more than 5\% sample of total area people was selected using purposive sampling technique after meeting the inclusion and exclusion criteria. A pre-test was conducted by ANMs, using a structured questionnaire in Hindi language after obtaining verbal consent. Health education was imparted using Health Modules on these four subjects. One and a half months later post-test was conducted using the same structured questionnaire.

Result: Total scores were added for each person for each topic. There were 333 (10.96\%) males and 2705 (89.04\%) females, making a total of 3038. The mean pre-test scores for Nutrition, Hypertension, Diabetes and Mental Health for respondents were 4.4 $\pm 1.12,5.89 \pm 1.47$, $4.25 \pm 1.88$ and $8.02 \pm 0.99$ respectively. The mean post-test scores showed highly statistically significant improvement 1 and $1 / 2$ months after the Health Education for Nutrition, Hypertension, Diabetes respectively (5.52 $\pm 1.04 ; p<0.0001, t=-3.9077),(7.15 \pm 1.35 ; p<0.0001, t=1.256)$, and $(6.26 \pm 1.66 p<0.0001)$. But the mean post-test score for Mental Health $(8.05 \pm 0.87 ; p=0.2097, t=0.03809)$ was not statistically significant.

Conclusion: The results of the study demonstrated that the health education through health modules is an effective way of improving the health-knowledge of slum people.

Keywords: Health Education, Nutrition, Hypertension, Diabetes, Mental Health 


\section{Introduction}

According to the World Bank, in 2002, approximately 750 million urban dwellers in developing countries lived on less than $\$ 2$ a day and 290 million lived on less than $\$ 1$ a day. ${ }^{1,2}$ An estimated 1 billion people around the world live in slums. UN-Habitat's statistics show that of the 862 million people living in slums worldwide, over 60 percent of them live in Asia (including West Asia). ${ }^{3}$

People coming to cities start living in slums, where dwellings are unfit for human habitation by reasons of dilapidation, overcrowding ... lack of ventilation, light or sanitation facility. The unhygienic living conditions pose high risk of communicable diseases and also the exposure to polluted air, contaminated water and food, and inadequate facilities for regular physical activity present acute and chronic disease hazards. Crowding, for example, tends to promote the transmission of infectious diseases like pneumonia, diarrhea, and tuberculosis. ${ }^{4}$ All characteristics of "slum-like" communities, are likely to produce poor health over and above the effects of simply living in a poor household and other individual-level characteristics. ${ }^{5}$

The census report 2011 of India identified 13.8 million households-about 64 million people-located in city slums nationwide. That's 17.4 per cent of all urban households, which account for roughly one-third of India's 1.2 billion people. New Delhi, the Indian capital, had a relatively low 15 per cent of households in slums, while major cities Kolkata and Chennai had 30 per cent and 29 per cent respectively. One-third slum homes were without indoor toilets. However, 70 per cent had televisions and 64 per cent had cellphones. That's about the same cellphone ownership rate as the general urban population and only slightly less than the number of general city dwellers with televisions. ${ }^{6}$ Around 49000 slum areas were estimated to be in existence in urban India between 2008 and 2009. In Delhi about 40\% of the households have a BPL ration card (red or yellow) and are eligible for subsidized rations. ${ }^{8}$ Slum populations are mostly heterogeneous.

Slum people have barriers to accept healthy practices: 1 . They may not understand why something being told to them is important for their health. 2. They may not have access to money and other resources.

Malnutrition is an endemic problem in India. The nutritional status and diet of slum children is very unsatisfactory. Their nutritional status is worst among all urban groups. In slums in addition to persisting challenges of communicable diseases and maternal health, people are confronted with a growing burden of Non-Communicable Diseases (NCDs). These are slow and generally cumulative in their effects and often become complicated as the subject becomes older. Mental well-being is associated with natural environment, sanitation, housing quality, sufficiency and durability, all of these are compromised in slums. ${ }^{9}$ They should be adequately educated and empowered to actively practice self-care and to utilize healthcare services. Awareness is an important determinant of health behaviors and actions to minimize health risks and injury.

The Community Health Department of a Tertiary Care Hospital is working in a slum community of Delhi. This study was taken up with the aim to find out whether exposure to Health awareness regarding Nutrition, Hypertension, Diabetes, and Mental Health issues in this community, brought about a change in the knowledge of community people or not.

\section{Material and Methods}

Study Site and Population: The study was carried out in the field practice area of a Tertiary Care Hospital in east Delhi. It has a population of 56502 (Males=28712 \& Females $=27790$ ) ${ }^{10}$

Study Design: A before and after study design was used.

Study Duration: January 2020 to May 2020

Study Sample: A total of 3038 persons of both genders were surveyed by house to house survey. It was a purposive sampling.

\section{Inclusion Criteria}

- Residents of Sunder Nagari.

- Age $>18$ years.

- Who gave the verbal consent to participate.

\section{Exclusion Criteria}

Visitors to area House-holds.

\section{Study Instrument}

- A Questionnaire Booklet: A structured pre-tested questionnaire booklet in Hindi with knowledge- based questions (eg. Symptoms of diseases, treatment) on the subjects of Nutrition, Hypertension, Diabetes and Mental Health was prepared. There were 5 questions on Nutrition with maximum marks up to 7, 6 questions on Hypertension with maximum marks up to 10,7 questions on Diabetes with maximum marks up to 9 and 7 questions on Mental Health with maximum marks up to 12. In all four health topics the answers to the last questions are not taken under the scheme of marking. The questions were printed for each topic twice, so to use them before the Health Education and then after 1- 1 and $1 / 2$ months.

- Health Education Modules: Health Education Modules prepared by the Community Health Department were used to impart knowledge on the Hypertension, Diabetes, and Mental Health. The Auxiliary Nurse Midwives (ANMs) had been health educating on Nutrition regularly during their home visits using charts and flex material prepared by the department. 


\section{Ethical Issues}

The study proposal was cleared by the Institutional Ethics Committee. Besides, informed verbal consent of the respondents was taken before eliciting information from each respondent.

\section{Methodology}

There are six ANMs in the Community Health Department. Each ANM has three to four blocks under her. Each ANM, home-visited one Block, one gali (lane) houses on first day (usually 20-22 houses). After exchanging the usual greetings she said that she wanted to know the household's knowledge of above mentioned health problems. So she conducted the pre-test by asking the adult house-hold members ( $>18$ years of age), questions related to these health problems as mentioned in the booklet and filled the pre-test paper for all the health problems. Then she found out what was cooked in the house and talked about healthy foods. She used Mental Health Module for each family at home and explained it in detail.

Next day she home-visited the same Block, second gali houses and after doing so called families of both the galies to attend Heath Education session. In this session she used 2 modules-Hypertension and Diabetes Modules to teach the area people. All the six ANMs home visited in the same manner.

They did the same in their next Block on day three and four.
So each ANM tried to cover all four Blocks allotted to her in this manner. Data was collected from 3038 respondents in a period of one and a half months.

To do post-test they repeated the home-visits of same houses in the manner mentioned above, only difference being, this time no health education wasgiven. This time they only had to fill the second set of paper in the booklet ie the post-test paper for each of the four topics. They could fill post-test for the same 3038 respondents in a month's time.

\section{Statistical Analysis}

Once the data was collected it was entered on excel sheet and analyzed. Total scores were added for each topic for each person. Thus the scores ranged from a low of 0 to a maximum of 12 for each of these four topics. Data was summarized by percentages, and mean. The student $T$ test was applied to find the statistically significant $p$ value. A p-value $<0.05$ was taken as significant.

\section{Result}

The Socio demographic details of the respondents showed that there were 333 (10.96\%) males and 2705 (89.04\%) females making a total of 3038 . Out of these maximum numbers ie 1014 (33.38) were in the age group of $>18-30$ followed by 910 (29.95) in >30-40 and then 581 (19.12) in $>40-50$. These three age groups covered more than $80 \%$ of participants [Table 1].

Table I.Socio demographic details of respondents

\begin{tabular}{|c|c|c|c|c|c|c|}
\hline Age & Total no. & $\%$ & Male & $\%$ & Female & $\%$ \\
\hline$\geq 18-30$ & 1014 & 33.38 & 112 & 3.69 & 902 & 29.69 \\
\hline$>30-40$ & 910 & 29.95 & 80 & 2.63 & 830 & 27.32 \\
\hline$>40-50$ & 581 & 19.12 & 59 & 1.94 & 522 & 17.18 \\
\hline$>50-60$ & 334 & 10.99 & 42 & 1.38 & 292 & 9.61 \\
\hline$>60$ & 199 & 6.55 & 40 & 1.32 & 159 & 5.23 \\
\hline Total & 3038 & 100.00 & 333 & 10.96 & 2705 & 89.04 \\
\hline
\end{tabular}

Table 2.Knowledge score of respondents about Nutrition assessed by pre-test and post-test in terms of Frequency, Percentage

\begin{tabular}{|c|c|c|c|c|}
\hline Scores & Pre-test & \% & Post-test & \% \\
\hline 0 & 1 & 0.03 & & \\
\hline 1 & 5 & 0.16 & & 0.03 \\
\hline 2 & 121 & 3.98 & 66 & 2.17 \\
\hline 3 & 489 & 16.10 & 313 & 10.30 \\
\hline 4 & 965 & 31.76 & 1393 & 45.85 \\
\hline 5 & 1081 & 35.58 & 493 & 16.23 \\
\hline 6 & 239 & 7.87 & 772 & 25.41 \\
\hline 7 & 137 & 4.51 & 3038 & 99.98 \\
\hline Total & 3038 & 100.00 & & \\
\hline
\end{tabular}


Table 3.Knowledge score of respondents about Hypertension, assessed by pre-test and posttest in terms of Frequency, Percentage

\begin{tabular}{|c|c|c|c|c|}
\hline Scores & Pre-test & \% & Post-test & $\%$ \\
\hline 1 & 2 & 0.07 & & \\
\hline 2 & 22 & 0.72 & 3 & 0.10 \\
\hline 3 & 97 & 3.19 & 31 & 1.02 \\
\hline 4 & 334 & 10.99 & 129 & 4.25 \\
\hline 5 & 672 & 22.12 & 964 & 31.73 \\
\hline 6 & 1067 & 35.12 & 881 & 29.00 \\
\hline 7 & 547 & 18.01 & 500 & 16.66 \\
\hline 8 & 139 & 4.58 & 289 & 9.51 \\
\hline 9 & 37 & 1.22 & 241 & 7.70 \\
\hline 10 & 121 & 3.98 & 3038 & 99.97 \\
\hline Total & 3038 & 100.00 & & \\
\hline
\end{tabular}

Table 4.Knowledge score of respondents about Diabetes, assessed by pre-test and post-test in terms of Frequency, Percentage

\begin{tabular}{|c|c|c|c|c|}
\hline Scores & Pre-test & $\%$ & Post-test & $\%$ \\
\hline 1 & 7 & 0.23 & & \\
\hline 2 & 639 & 21.03 & 55 & 1.81 \\
\hline 3 & 808 & 26.60 & 210 & 6.91 \\
\hline 4 & 326 & 10.73 & 230 & 7.57 \\
\hline 5 & 248 & 8.15 & 162 & 5.33 \\
\hline 6 & 439 & 14.45 & 989 & 32.55 \\
\hline 7 & 530 & 17.45 & 892 & 29.36 \\
\hline 8 & 25 & 0.82 & 122 & 4.02 \\
\hline 9 & 16 & 0.51 & 378 & 12.44 \\
\hline Total & 3038 & 99.97 & 3038 & 100.00 \\
\hline
\end{tabular}

Table 5.Comparison of pre-test and post-test knowledge score of respondents about Mental Health assessed in terms of Frequency, Percentage

\begin{tabular}{|c|c|c|c|c|}
\hline Scores & Pre-test & $\%$ & Post-test & $\%$ \\
\hline 4 & 3 & 0.10 & & \\
\hline 5 & 32 & 1.05 & 6 & 0.20 \\
\hline 6 & 107 & 3.52 & 32 & 1.05 \\
\hline 7 & 740 & 24.36 & 782 & 25.29 \\
\hline 8 & 1181 & 38.87 & 1300 & 42.88 \\
\hline 9 & 843 & 27.75 & 819 & 27.31 \\
\hline 10 & 106 & 3.49 & 79 & 2.65 \\
\hline 11 & 22 & 0.72 & 14 & 0.44 \\
\hline 12 & 4 & 0.13 & 6 & 0.1 \\
\hline Total & 3038 & 100.00 & 3038 & 99.92 \\
\hline
\end{tabular}

The knowledge score of respondents on Nutrition (Table2), Hypertension (Table3), and Diabetes (Table 4), assessed by pre-test and post-test showed marked improvement respectively that were found to be statistically significant 
too. For Nutrition 2422 (79.72\%) respondents scored more than 3 out of 7 in pre-test and 2971 (96.71\%) in post-test. The mean pre-test score $4.4 \pm 1.12$ showed highly statistically significant improvement, 1 and $1 / 2$ months after Health Education, that is, $(5.52 \pm 1.04 ; \mathrm{p}<0.0001, \mathrm{t}=-3.907)$. For Hypertension 2582(85.03\%) respondents scored more than Five out of 10 in pre-test and 3004(98.85\%) in post-test. The mean pre-test score $5.89 \pm 1.47$ and post-test score (7.15 $\pm 1.35 ; p<0.0001, t=1.256)$ with statistical significance. Similarly the knowledge score on Diabetes showed marked improvement, that is, $1258(41.38 \%)$ respondents scored 5 and more out of 9 in pre-test and more than double number of respondents $2543(84.7 \%)$ in post-test. The mean pretest score was $4.25 \pm 1.88$ which showed highly statistically significant improvement to $(6.26 \pm 1.66 \mathrm{p}<0.0001)$ in posttest.

The score of participants about Mental Health showed very little improvement as the pre-test score was already high 3003(98.84\%) respondents scored 6 and more out of 12 in pre-test and $3032(99.72 \%$ ) in post-test (Table 5). The mean pre-test score was $8.02 \pm 0.99$ and after the Health Education, that is, (mean $=8.05 \pm 0.87 ; p=0.2097, t=0.03809$ ), which was not statistically significant.

\section{Discussion}

In our study, knowledge score of respondents on nutrition, hypertension, and diabetes, assessed by pre-test and posttest showed marked improvement. In a study, significant improvement in knowledge on Diabetes was observed among the general population of Sikkim after a diabetic education programme. ${ }^{11}$

The score of participants about Mental Health in our study showed very little improvement as the pre-test score was already high. This can be explained as a lot of work on Mental Health had been done in the field practice area of CHD in recent years. Capacity building of Community Mental Health Workers, Awareness generation activities including mental health awareness sessions, rallies, roadshows, mental health mela etc. had been done extensively in the area. This was done under a project supported by The Hans Foundation. ${ }^{12}$

Education of ... and sensitization of the community about the causes, symptoms, and treatment of .... disease have been emphasized by the Government of India. However, there is a need to strengthen the health and nutritioneducation initiatives. ${ }^{13}$

A lot of emphasis is being given to Health and Education and their intercepting relationship. The 1978 Alma Ata International Conference on Primary Health Care defined "health" to include "a state of complete physical, mental and social well-being" ${ }^{14}$ - which we see as largely products of education. Students go to schools to get education similarly a public health person uses health education methods to teach about diseases and their prevention and treatment to his/her community. Attainment of a certain level of formal education by young adults affects lifelong health through multiple pathways. Just as many areas of daily life are recognized domains of legitimate public health action ... so should education (beyond health education in schools) be recognized as a legitimate domain of public health action. ${ }^{15}$

Health Education of community is of utmost importance. As an example we find that in case of home management of diarrhoea, National Family Health Survey - 3 (NFHS - 3) though provided all information as recommended by UNICEF, yet only 8 percent of children with diarrhoea received what was recommended for proper management of diarrhea. This suggests the need for public education programmes ...... ${ }^{16}$ Similarly one finds highly educated people lacking in health knowledge regarding their diseases such as Hypertension and/or Diabetes. They need to be health educated.

In another project, The STEPS project they aimed at making available information, Health education through counseling, demonstration, exhibition, to bring about attitudinal and behavioral changes in the target groups about health issues. ${ }^{17}$ These health education activities should be done on a regular basis. In another study, the health awareness and health promotion activities in slums were found to be not on regular basis and not throughout the year. ${ }^{18}$

In our study though the respondents comprised $5 \%$ of the whole community, yet it was a big number and it was represented from each block.

\section{Conclusion}

The study reveals that contact through lane-approach and reinforcement by use of Health Modules, were instrumental in creating Nutrition, Hypertension, Diabetes, and Mental Health issues awareness, improved knowledge and better retention amongst the respondents. This could encourage them to adopt a positive attitude towards healthy life-style.

In this study, Auxiliary Nurse Midwives (ANMs) formed the backbone of our intervention. Similarly Government Organizations (GOs) and NGOs need to focus on capacity building of community health workers (CHWs) including ASHA Workers, ANMs, LHVs, PHNs and Anganwadi Workers by imparting more and more knowledge on Health issues. The CHWs should be encouraged to use flip charts/modules/ communication materials for health awareness in the communities they serve.

\section{Acknowledgement}

The authors acknowledge the good work of ANMs under 
Integrated Health Unit of Community Health Department, St. Stephen's Hospital in imparting the health knowledge to the area people - the participants of this study.

\section{Financial Implication: None \\ Conflict of Interest: None}

\section{References}

1. Baker JL. Urban poverty: a global view (English). Urban Papers; no. UP-5. Washington, DC: World Bank 2008. Available from: http://documents.worldbank.org/ curated/en/954511468315832363/Urban-poverty-aglobal-view accessed on 18.4.2020.

2. Ravallion M. Urban poverty. Finance and Development. 2007; 44(3). Available from: http://www.imf.org/ external/pubs/ft/fandd/2007/09/ravalli.htm - accessed on 20.4.2020.

3. Mathur OP. 'Urban Poverty in Asia'. Study Prepared for the Asian Development Bank. 2013. Available from: https://www.adb.org/sites/default/files/projectdocument/81002/urban-poverty-asia.pdf accessed on 18.4.2020.

4. Unger A, Riley LW. Slum health: from understanding to action. PLoS Medicine. 2007;4:1561-6. [PMC free article] [PubMed] [Google Scholar] Available from: journals.plos.org > plosmedicine > article > journal. pmed.0040295. Accessed on 26.4.2020.

5. Rice J, Rice JS. The concentration of disadvantage and the rise of an urban penalty: urban slum prevalence and the social production of health inequalities in the developing countries. International Journal of Health Services 2009; 39: 749-770. Available from: journals. sagepub.com [PubMed] [Google Scholar] Accessed on 25.4.2020.

6. "India census says 1 in 6 lives in unsanitary slums." The Associated Press. Posted: Mar 22, 2013 11:11 AM ET. Available from: https://www.cbc.ca/news/world/indiacensus-says-1-in-6-lives-in-unsanitary-slums-1.1403897, accessed on 20.4.2020.

7. National Press Information Bureau, Government of India. National Sample Survey Organization (NSSO) report "Some Characteristics of Urban Slum 2008-2009" Ministry of Housing and Urban Poverty Alleviation. 2011. Available from: https://pib.gov.in/newsite/PrintRelease. aspx? relid=72280. accessed on 24.4.2020.

8. Banerjee A, Pande R, Walton M. Working Paper International Growth Centre (IGC). 'Delhi's Slum Dwellers Deprivation, Preferences and Political Engagement among the Urban Poor', 2012. Available at https://www. theigc.org/wp-content/uploads/2014/10/Banerjee-EtAl-2012-Working-Paper-1.pdf Accessed on 30.4.2020.

9. Gruebner $\mathrm{O}$, Khan $\mathrm{MMH}$, Lautenbach $\mathrm{S}$, Müller D, Krämer A, Lakes T. Mental health in the slums of Dhaka - a geo-epidemiological study. BMC Public Health 2012;
12: Article number: 177. Available from: https://www. ncbi.nlm.nih.gov/pmc/articles/PMC3361672/ Accessed on 30.4.2020

10. MIS 2020. Community Health Department, St. Stephen's Hospital.

11. Pal R, Pal S, Barua A, Ghosh MK. Health education intervention on diabetes in Sikkim - NCBI. Indian J Endocrinol Metab 2010; 14(1): 3-7. Available from: www. ncbi.nlm.nih.gove > pmc > articles> PMC3063532 accessed on 12.5.2020.

12. Gupta S, Mangal A, Gupta V, Vaghela JF, Kumar A. Integrating Mental Health Interventions with Primary Care: An Experience from an Urban Slum of Delhi, India. Int J Preven Curat Comm Medicine 2018; 4(1): 19-26. Available from: https://medical.adrpublications.in/ index.php/Preventive-Curative-CommunityMed/article/ view/1439/pdf accessed on 28.5.2020.

13. International Institute for Population Sciences. National Family Health Survey-1. NFHS-1: India 199293. Mumbai: International Institute for Population Sciences; 1995. p.262.[Google Scholar] Available at https://dhsprogram.com/pubs/pdf/FRIND3/FRIND3Vol1AndVol2.pdf accessed on 17.5.2020.

14. World Health Organization. Declaration of Alma-Ata. 1978 Available from: www.who.int s publications , almaata_declaration_en Accessed on 10.5.2020

15. Hahn RA, Truman BI. Education Improves Public Health and Promotes Health Equity. Int J Health Serv 2015; 45(4): 657-678. Available at : https://pubmed.ncbi.nlm. nih.gov/25995305/ Accessed on 13.5.2020.

16. International Institute for Population Sciences (IIPS) and Macro International. 2007. National Family Health Survey (NFHS-3), 2005-06: India: Volume I. Mumbai: IIPS. Available from: https://dhsprogram.com/pubs/ pdf/FRIND3/FRIND3-Vol1AndVol2.pdf accessed on 17.5.2020.

17. Prameelamma P. "Serve Train Educate People's Society" - STEPS - Making More Health: Achieving Individual, Family and Community Well-Being. Integrated project for Clinical services, Health Awareness and Community development of slum people in India. Available at https://www.changemakers.com/morehealth/entries/ integrated-project-clinical-services-health-awareness-a 25.5.2020 FAQs.

18. Zaman TU, Dutta SK. Struggle of Slum Dwellers for Maintaining their Health Status and Behavior in a Slum Pocket of Guwahati City. International Journal of Medical Research \& Health Sciences 2018: 7(7): 63-71. ISSN No: 2319-5886 Available from:https://www.ijmrhs. com/medical-research/struggle-of-slum-dwellersfor-maintaining-their-health-status-and-behaviorin-a-slum-pocket-of-guwahati-city.pdf accessed on 27.5.2020. 


\section{The Questionnaire Booklet in Hindi}

\section{हाई ब्लड प्रेशर (उच्च रक्त चाप)}

1. नार्मल बलड प्रेशर (बी.पी) कितना होता है।

क ) $140 / 90$ ख ) $155 / 80$ ग )<120/80 घ ) $120 / 90$

2 . हाई ब्लड प्रेशर के लक्षण क्या हैं।

क) सिरदर्द ख) चक्कर आना ग ) खून की कमी घ) पैरों में खुजली

इ ) नकसीर फूटना ।

3. कुछ रोगियों में हाई ब्लड प्रेशर के लक्षण कहीं होते चेक करवाने पर ही पता लगता है क्या यह सही है।

हाँ / नहीं

4. हाई बी.पी से शरीर के किन हिस्सों पर दुष्प्रभाब पड़ता है। हाथ पै /गुर्द / दिल / चमड़ी / आँख / नाक / लिवर / कान

5. निम्नलिखित प्रश्न के एक गलत उत्तर पर चिन्ह लगायें।

हाई बी.पी होने पर|

क) दवाई डॉक्टर की सलाह के अनुसार नियमित रूप से खानी है

ब ) नमक कम खाना है

ग ) घी, तैल, मक्खन अधिक खाना है।

घ ) व्यायाम करना है।

6. हाई बी. पी की दवाई मरीज़ को कब तक खानी होती है।

(क) 1 साल तक (ख) 6 माह तक (ग) उम भर (घ) 5 साल तक 7. घर में इनको ये बीमारी है, यदि हाँ, तो नाम लिखें -

\section{हाई ब्लड प्रेशर (उच्च रक्त चाप)}

2. नार्मल ब्लड प्रेशर (बी.पी) कितना होता है।

क ) $140 / 90$ ख ) $155 / 80$ ग ) $<120 / 80$ घ ) $120 / 90$

2. हाई ब्लड प्रेशर के लक्षण क्या हैं।

क) सिरदर्द ख) चक्कर आना ग ) खून की कमी घ) पैरों में खुजली

इ ) नकसीर फूटना ।

3. कुछ रोगियों में हाई ब्लड प्रेशर के लक्षण नहीं होते चेक करवाने पर ही पता लगता है क्या यह सही है।

हों / नहीं

4. हाई बी.पी से शरीर के किन हिस्सों पर दुष्प्रभाव पड़ता है। हाथ पै /गुर्द / दिल / चमड़ी / ऑख / नाक / लिवर / कान

5. निम्नलिखित प्रश्न के एक गलत उत्तर पर चिन्ह लगायें। हाई बी.पी होने पर।

क) दवाई डॉक्टर की सलाह के अनुसार नियमित रूप से खानी है

ब ) नमक कम खाना है

ग ) घी, तैल, मक्खन अधिक खाना है।

घ ) व्यायाम करना है।

6. हाई बी. पी की दवाई मरीज़ को कब तक खानी होती है।

(क) 1 साल तक (ख) 6 माह तक (ग) उम भर (घ) 5 साल तक 7. घर में इनको ये बीमारी है, यदि हों, तो नाम लिखें - 


\section{डायबिटीज ( मधुमेह )}

1. डायबिटीज की बीमारी से आप क्या समझते हैं।

2. खून में खाली पेट शुगर की मात्रा कितनी होने पर हम कहेंगे की किसी रोगी को डायबिटीज है। एक सही उत्तर पर चिन्ह लगाएं।

क ) $130 \mathrm{mg} \%$ ख ) $126 \mathrm{mg} \%$ ग ) $86 \mathrm{mg} \%$ घ) $110 \mathrm{mg} \%$

3. क्या शुगर के रोगी को शकरकंदी और आलू खाना चाहिए।

$\begin{array}{ll}\text { (क) हाँ (ख) नहीं } & \end{array}$

4. शुगर की बीमारी के कोई तीन लक्षण बताएं।

(क)

(ख)

(ग)

5. क्या शुगर के रोगी को हाई बी.पी भी हो सकता है

क) हाँ ख ) नहीं

6. क्या शुगर की बीमारी पारिवारिक है।

$\begin{array}{ll}\text { क ) हाँ } & \text { खहीं }\end{array}$

7. डायबिटीज का इलाज़ कितने समय तक करना होगा।

क) 1 साल तक ख ) 6 माह तक ग ) उम भर घ ) 5 साल तक 8. घर में इनको ये बीमारी है, यदि हाँ, तो नाम लिखें -

\section{डायबिटीज ( मधुमेह )}

1. डायबिटीज की बीमारी से आप क्या समझते हैं।

2. खून में खाली पेट शुगर की मात्रा कितनी होने पर हम कहेंगे की किसी रोगी को डायबिटीज है। एक सही उत्तर पर चिन्ह लगाएं। क ) $130 \mathrm{mg} \%$ ख ) $126 \mathrm{mg} \%$ ग ) $86 \mathrm{mg} \%$ घ ) $110 \mathrm{mg} \%$

3. क्या शुगर के रोगी को शकरकंदी और आलू खाना चाहिए।

$\begin{array}{ll}\text { (क) हाँ } & \text { (ख ) नहीं }\end{array}$

4. शुगर की बीमारी के कोई तीन लक्षण बताएं।
(ब)
(ग)

(क)

5. क्या शुगर के रोगी को हाई बी.पी भी हो सकता है

क ) हाँ ख ) नहीं

6. क्या शुगर की वीमारी पारिवारिक है।

क ) हाँ ख) नहीं

7. डायबिटीज का इलाज़ कितने समय तक करना होगा।

क ) 1 साल तक ख ) 6 माह तक ग) उम भर घ) 5 साल तक

8. घर में इनको ये बीमारी है, यदि हाँ, तो नाम लिखें - 


\section{मानसिक स्वास्थय}

1. क्या आपने किसी मानसिक रोगी को देखा है? यदि हाँ तो उसके विषय में लिखें -
(i) बालः (क) बने हुए (ख) छितरे हुए
(ii) समझः (क) ठीक (ख) ठीक नहीं
(iii) लार: (क) टपकती हुयी (ख) नहीं टपकती हुयी
(iv) कपड़े: (क) साफ़ सुथरे (ख) गंदे
(v) बोलना: (क) कम बोलना (ख) नहीं बोलना (ग) ठीक बोलना
(vi). नहाना धोना: (क) नहीं करना (ख) साफ़ रहता है
(vii) अपने आप से बात करना
(viii) चिड़चिड़ाना
(ix) नींद (क) ज्यादा (ख) कम (ग) नार्मल (घ) बहुत ज्यादा

2. बह्त ज्यादा दुखी होना (डिप्रेशन)

(क) एक बीमारी है (ख) नॉर्मल व्यक्ति को भी हो सकती है

3. बहुत ज्यादा चिंता करना:

(क) एक बीमारी है (ख) नॉर्मल व्यक्ति को भी हो सकती है

4. बहुत ज्यादा गुस्सा करना:

(क) एक बीमारी है (ख) नॉर्मल व्यक्ति को भी हो सकती है

5. बहुत ज्यादा बोलना:

(क) एक बीमारी है (ख) नॉर्मल व्यक्ति को भी हो सकती है

6. घर में इनको ये बीमारी है, यदि हों, तो नाम लिखें।

\section{मानसिक स्वास्थय}

1. क्या आपने किसी मानसिक रोगी को देखा है? यदि हाँ तो उसके विषय में लिखें -
(ii) बालः (क) बने हुए (ख) छितरे हुए
(ii) समझः (क) ठीक (ख) ठीक नहीं
(iii) लार: (क) टपकती हुयी (ख) नहीं टपकती हुयी
(iv) कपड़े: (क) साफ़ सुथरे (ख) गंदे
(vi) बोलना: (क) कम बोलना (ख) नहीं बोलना (ग) ठीक बोलना
(vi). नहाना धोना: (क) नहीं करना (ख) साफ़ रहता है
(vii) अपने आप से बात करना
(viii) चिड़चिड़ाना
(ix) नींद (क) ज्यादा (ख) कम (ग) नार्मल (घ) बहतत ज्यादा

2. बह्त ज्यादा दुखी होना (डिप्रेशन)

(क) एक बीमारी है (ख) नॉर्मल व्यक्ति को भी हो सकती है 3. बहुत ज्यादा चिंता करना:

(क) एक बीमारी है (ख) नॉर्मल व्यक्ति को भी हो सकती है 4. बह्त ज्यादा गुस्सा करना:

(क) एक बीमारी है (ख) नॉर्मल व्यक्ति को भी हो सकती है 4. बह्त ज्यादा बोलना:

(क) एक बीमारी है (ख) नॉर्मल व्यक्ति को भी हो सकती है 6. घर में इनको ये बीमारी है, यदि हाँ, तो नाम लिखें। 


\section{नुट्रिशन/ पोषण}

1. पोषण शब्द से आप क्या समझते हैं।

(क) भोजन (ख) दोपहर का खाना (ग) नाश्ता घ) बढ़ना

2. भोजन के तत्व क्या क्या हैं? निशान लगाईये।

(क) प्रोटीन (ख) स्कर्वी (ग) वसा (घ) कार्बाहाइड्रेट (ड) एलर्जी

3. ढूध, दही, पनीर, दाल, मांस, मछली में क्या क्या पाया जाता है।

क ) प्रोटीन ख ) वसा $\quad$ ग) कार्बॉहाइड्रेट

4. लोह तत्व की कमी से होने वाली बीमारी कौन कौन सी हैं।

(क) टाइफाइड (ख) मलेरिया (ग) अनीमिया (घ) दस्त (इ) उल्टी

5. हड्डियों की मजबूती के लिए जरूरी है -

फल / सब्जियां / कैल्शियम / विटामिन / प्रोटीन

6. क्या आपने घर में किसी को कुपोषण है, तो नाम लिखें -

\section{नुट्रिशन/ पोषण}

1. पोषण शब्द से आप क्या समझते हैं।

(क) भोजन (ख) दोपहर का खाना (ग) नाश्ता घ) बढ़ना

2. भोजन के तत्व क्या क्या हैं? निशान लगाईये।

(क) प्रोटीन (ख) स्कर्वी (ग) वसा (घ) कार्बोहाइड्रेट (ड) एलर्जी

3. टूध, दही, पनीर, दाल, मांस, मछ्ली में क्या क्या पाया जाता है।
क ) प्रोटीन
ख ) वसा
ग) कार्बाहाइड्रेट

4. लोह तत्व की कमी से होने वाली बीमारी कौन कौन सी हैं।

(क) टाइफाइड (ख) मलेरिया (ग) अनीमिया (घ) दस्त (ड) उल्टी

5. हड्डियों की मजबूती के लिए जरूरी है -

फल / सब्जियां / कैल्शियम / विटामिन / प्रोटीन

6. क्या आपने घर में किसी को कुपोषण है, तो नाम लिखें - 